\title{
Spatial-temporal analysis of the diet of a non-native fish in the Santa Cruz Reservoir, Brazilian semi-arid
}

\author{
Análise espaço-temporal da dieta de um peixe não nativo no reservatório de Santa Cruz,
} semiárido brasileiro

Jônnata Fernandes de Oliveira ${ }^{1}$, Jean Carlos Dantas de Oliveira², José Luís Costa Novaes²,

Antonia Elissandra Freire de Souza², Marla Melise Oliveira de Sousa²,

Andréa Bezerra dos Santos ${ }^{3}$ and Danielle Peretti ${ }^{3 *}$

${ }^{1}$ Instituto Federal de Educação, Ciência e Tecnologia do Maranhão - IFMA, Campus Avançado Carolina, Praça do Estudante, s/n, Bairro Centro, CEP 65980-000, Carolina, MA, Brasil

${ }^{2}$ Centro de Ciências Biológicas e da Saúde, Universidade Federal Rural do Semi-Árido - UFERSA, BR 110, Km 47, Bairro Costa e Silva, CEP 59625-900, Mossoró, RN, Brasil

${ }^{3}$ Departamento de Ciências Biológicas, Universidade do Estado do Rio Grande do Norte - UERN, Av. Prof. Antônio Campos, s/n, Bairro Costa e Silva, CEP 59625-620, Mossoró, RN, Brasil *e-mail: danielleperetti@uern.br

Cite as: Oliveira, J.F. et al. Spatial-temporal analysis of the diet of a non-native fish in the Santa Cruz Reservoir, Brazilian semi-arid. Acta Limnologica Brasiliensia, 2018, vol. 30, e110.

Abstract: Aim: The diet of Plagioscion squamosissimus present in the Santa Cruz Reservoir, Rio Grande do Norte, Brazil, was investigated, evaluating the influences of spatial and temporal variations and abiotic factors in the utilization of food resources. Methods: The samplings were performed quarterly between February 2011 and November 2014. Of the 525 specimens captured, 375 presented food items in the stomachs. The diet was determined using: (i) Feeding Index (IAi); (ii) and the graphical interpretation of the food strategy through non-metric multidimensional scaling (NMDS) analyzes, the differences in diet being tested from Permutational Multivariate Analyzes of Variance (PERMANOVA). To verify if environmental variables influence the Canonical Correspondence Analyzes (CCA) were used, using the data from the IAi the environmental data, being the significance of the axes tested through Monte Carlo simulations. Results: The species feed mainly on items of animal origin, vegetable being a resource ingested accidentally. The diet was composed of shrimp, fish, insect, mollusk and vegetable, the latter rarely found. The shrimp was the main item $(92.57 \%)$ and the insects (7.24\%) accessory items. Spatial and temporal ordering demonstrated that the species didn't present variation in diet composition, as well as a low association between diet and environmental variables. Conclusion: P. squamosissimus is characterized as carcinophagous, due to the predominance of shrimp in its diet, evidencing that the species is adapted to the conditions offered by the Brazilian semi-arid environment.

Keywords: food strategy; lentic ecosystem; Plagioscion squamosissimus; Neotropical semi-arid.

Resumo: Objetivo: Investigou-se a dieta de Plagioscion squamosissimus presente no reservatório de Santa Cruz, Rio Grande do Norte, Brasil, avaliando as influências das variaçôes espacial e temporal e de fatores abióticos na utilizaçáo dos recursos alimentares. Métodos: As coletas foram realizadas trimestralmente, entre fevereiro de 2011 e novembro de 2014. Dos 525 exemplares capturados, 375 apresentaram itens alimentares nos estômagos. A dieta foi determinada utilizando: (i) Índice 
Alimentar (IAi); (ii) e a interpretação gráfica da estratégia alimentar, através de análise de Escalonamento Multidimensional Não Métrico (NMDS), sendo as diferenças na dieta testadas a partir de Análises de Variância Multivariada Permutacional (PERMANOVA). Para verificar se as variáveis ambientais influenciam na dieta foram realizadas Análise de Correspondência Canônica (CCA), usando os dados do IAi e os dados ambientais, sendo a significância dos eixos testada através de simulaçóes de Monte Carlo. Resultados: A espécie se alimentou principalmente de itens de origem animal, sendo vegetal um recurso ingerido de forma acidental. A dieta foi composta por camarão, peixe, inseto, molusco e vegetal, este último raramente encontrado. O camaráo foi o item principal $(92,57 \%)$ e os insetos $(7,24 \%)$ itens acessórios. A ordenação espacial e temporal demonstrou que a espécie não apresentou variação na composição da dieta, assim como apresentou uma baixa associação entre a alimentaçáo e as variáveis ambientais. Conclusáo: P. squamosissimus caracteriza-se como carcinófaga, em função do predomínio de camarão em sua dieta, evidenciando que a espécie está adaptada às condiçóes oferecidas pelo ambiente do semiárido brasileiro.

Palavras-chave: estratégia alimentar; ecossistema lêntico; Plagioscion squamosissimus, semiárido Neotropical.

\section{Introduction}

In aquatic environments, variations in temperature, water level and rainfall are common throughout the year, resulting in cyclical changes in the abundance of available food, resulting in changes in fish diet (Oliveira et al., 2016a; Souza et al., 2017). Hydrological variations are also responsible for the quantitative and qualitative changes in the availability of food resources, and at certain times some food sources undergo rapid changes becoming scarce or abundant, such as in the rainy season (Gandini et al., 2012; Silva et al., 2012). Another important factor to consider is the great spatial-temporal heterogeneity found in these environments, since in high water periods new habitats for feeding, in which the fish frequently pass, influencing the type of food ingested and the abundance of fish (Loures \& Pompeu, 2012; Gandini et al., 2014).

In semi-arid freshwater ecosystems, water level fluctuations often occur because of prolonged drought, which is a result of irregular rains and high temperatures, characteristic of the region's climate, with little depth (Araújo et al., 2016). These characteristics, associated with the long period of drought, had a fundamental role in the policy of damming rivers to overcome water shortages and favor the development of fishing (Novaes et al., 2014), besides the introduction of allochthonous fish over time. An important point is that the success of introduced species implies, for the most part, competition, predation, inhibition of reproduction, modification of the environment, transfer of parasites or diseases and hybridization (Agostinho et al., 2007).

The ichthyofauna of the semi-arid watersheds represents the result of ecological processes that determined the adaptation of species to the climatic conditions and the hydrological regime of the region (Costa Lima et al., 2017). However, the modification of these environments was performed without any concern with the biota and for a long time there wasn't knowledge of the consequences that the ecosystem would suffer (Agostinho et al., 2007). All these aspects support the need for research on food ecology, because from the knowledge of the fish diet, the specific abundance of the items consumed and the role it produces in the ecosystem, it is possible to better understand the inter-relations between the community components and to support future management practices and conservation of these ecosystems.

Among the species introduced in this region are the white hake, Plagioscion squamosissimus (Heckel, 1840), which exhibits nocturnal benthic-pelagic behavior and inhabits lakes and river banks of white, clear, black and mixed waters (Siqueira-Souza \& Freitas, 2004; Yamamoto et al., 2004), demonstrating this versatility in the exploration of the environment, which is why it can adapt perfectly in artificial ecosystems. This characteristic of the high tolerance of the species to the environmental variations surpasses the performance of the native species and can still result in reduction or local extinction due to competition, predation and parasitism, which can trigger initiate a cascade effect in the whole community (Reis \& Santos, 2014).

In the Northeast of Brazil, the diet of P. squamosissimus is based on the consumption of shrimp, characterizing it as carcinophagous (Gavilan-Leandro et al., 2009; Ferreira Filho et al., 2014; Santos et al., 2014; Gurgel-Lourenço et al., 2015; Oliveira et al., 2016b). In other regions of Brazil, the diet was based on the consumption of fish, thus characterizing the species as a piscivorous (Santos, 1995; Almeida et al., 1997; 
Hahn et al., 1997; Braga, 1998; Hahn et al., 1999; Cassemiro et al., 2005; Bennemann et al., 2006; Santos et al., 2014).

In this way, the pressure by this introduced species on the native communities motivated a more thorough investigation in relation to food ecology and possible variables in the availability of food resources, such as variations in space and time, and the influence of environmental factors in the diet. Thus, the diet of Plagioscion squamosissimus present in the Santa Cruz Reservoir, Apodi, Rio Grande do Norte, Brazil, was investigated qualitatively and quantitatively, as well as the possible influence of spatial-temporal variation and abiotic factors on the use of food resources.

\section{Materials and Methods}

\subsection{Study area}

The Santa Cruz Reservoir is in the Apodi-Mossoró River Basin, Apodi, Rio Grande do Norte, Brazil (Figure 1). This reservoir is the largest in this basin with a capacity of approximately 600 million $\mathrm{m}^{3}$ of water (SEMARH, 2014) and was built in 2002 with the objective of irrigating 9,236 ha in the Apodi, controlling the flood and to regulate the flow of the Apodi-Mossoró River, to serve as a buffer for the waters of the São Francisco River, and to ensure water supply to 27 cities in the Upper West Potiguar (Pacheco \& Baumann, 2006).

\subsection{Abiotic data collection}

The variables of water temperature $\left({ }^{\circ} \mathrm{C}\right)$, transparency $(\mathrm{cm})$, hydrogen ionic potential $(\mathrm{pH})$, electrical conductivity $\left(\mu \mathrm{S} . \mathrm{cm}^{-1}\right)$, dissolved oxygen $(\mathrm{mg} / \mathrm{l})$ and total dissolved solids (TDS) $(\mathrm{g} / \mathrm{L})$ were measured to characterize the environment and to verify possible relation between limnological surface water variables and diet of the species under study, through a multiparameter meter (HORIBA, U-50) and the transparency $(\mathrm{cm})$ verified by the Secchi disk. Obtained in three moments: (i) installation of gillnet, (ii) expense (iii) withdrawal of gillnets. For the characterization of rainfall, precipitation data were used through the Agricultural Research Company of Rio Grande do Norte (Empresa Brasileira de Pesquisa Agropecuária - EMBRAPA). The characteristics of the environments, the soil is sandy with no erosion and presence of stones. The marginal vegetation is formed by grasses and shrubs, being considered narrow and very narrow.

\subsection{Fish catch}

The sampling was done quarterly between February 2011 and November 2014, in eight points distributed along the reservoir as follows: points 1 and 2 near the dam, 3 and 4 in the central part, 5 and 6 in the transition area, 7 and 8 at the mouth of the river (Figure 1). The catches were standardized, and at each point were placed 11 waiting gillnets with meshes ranging from

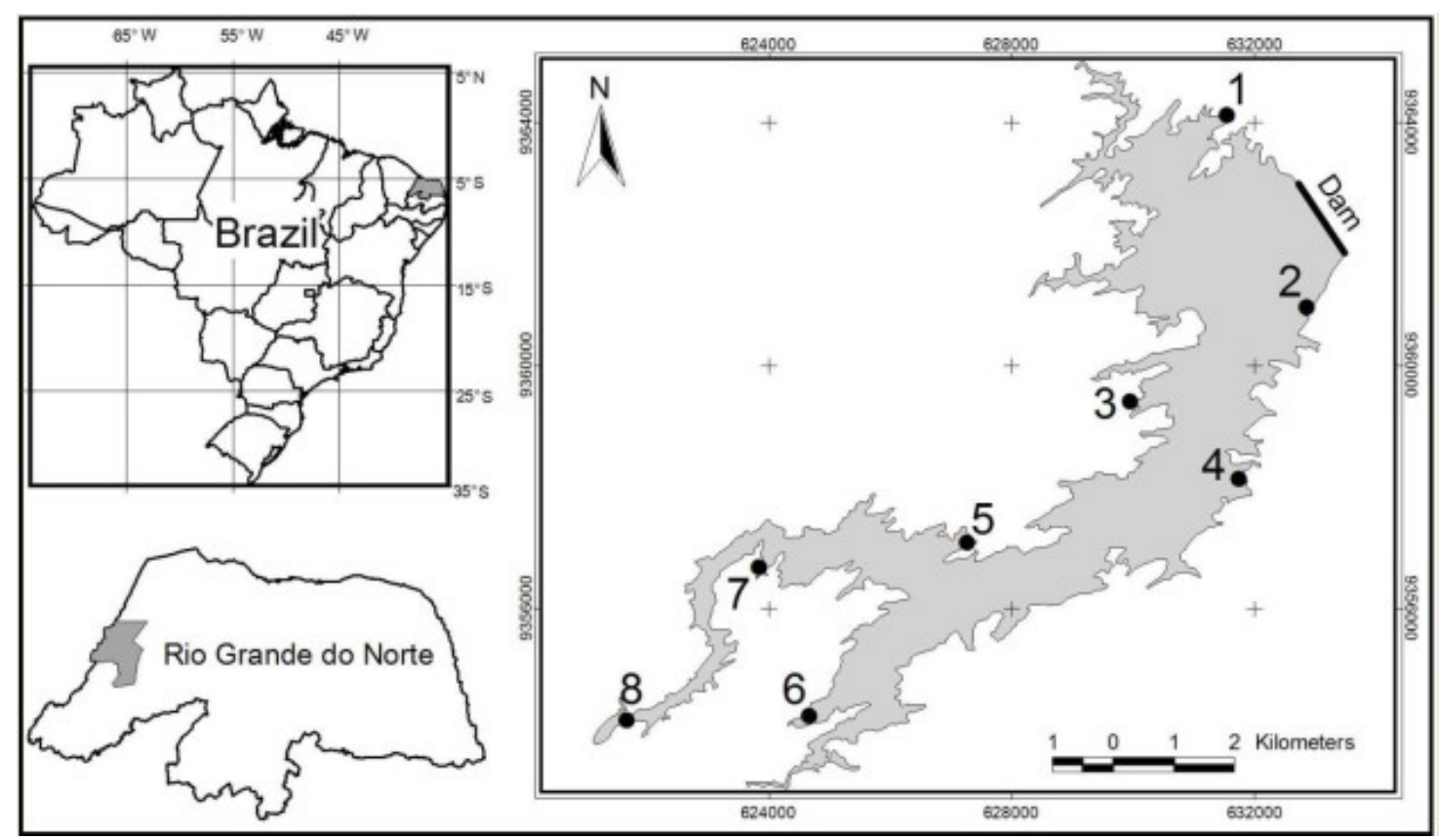

Figure 1. Santa Cruz Reservoir is in the Apodi-Mossoró River Basin, Apodi, Rio Grande do Norte, Brazil. The positions of collection sites 1 and 8 are shown. 
12 to $70 \mathrm{~mm}$ (between adjacent nodes), which were installed at 5:00 p.m., with two outfalls at 9:00 p.m. and 5:00 a.m. After capture, the fish were transported for identification procedures and biometrics in the laboratory, where the stomachs were removed for analysis of the contents, being discarding the voids and conserving those with content.

\subsection{Food content analysis}

Stomach contents were analyzed under a stereomicroscope, being the item identified to the lowest possible taxonomic level, using specialized bibliography (McCafferty, 1981; Needham \& Needham, 1982; Merritt \& Cummins, 1996). Then, the volume of the items was obtained through graduated beakers or through petrified plate (transformed in $\mathrm{ml}$ ) (Hellawell \& Abel, 1971). After that, the frequencies of occurrence and volume were calculated (Zavala-Camin, 1996), whose association gives the calculation of the Feeding Index (IAi) (Kawakami \& Vazzoler, 1980), in percentage, described by the equation: $I A i=[F o . F v \Sigma(F o . F v)] \times 100$. To evaluate the preferential food items and determine the dietary habits of the species, it was used the scale proposed by Rosecchi \& Nouaze (1985), where IAi > 50\% represents a preferred item; IAi between $25 \%$ and $50 \%$ secondary item, and $\mathrm{IAi}<$ than $25 \%$ accessory item.

\subsection{Statistical analysis}

The Feeding Index (IAi) of P. squamosissimus was calculated for all points and months sampled, and these data were used in a similarity matrix using the Bray-Curtis similarity index. To verify spatial and temporal organization in the diet of the species, the results of this procedure were used in Non-Metric Multidimensional Scaling (NMDS) analyzes, and to test differences in diet were realized Permutational Multivariate Analyzes of Variance (PERMANOVA) through the Bray-Curtis similarity index. To verify if the environmental variables influence in the diet, Multivariate Canonical Correspondence Analyzes (CCA) was used, using the data of the IAi of the species and the environmental data, determined in each point and month of sample, being the significance of the axes tested through simulations of Monte Carlo (1000 simulations). The PAST (Paleontological Statistics software) program version 3.14 was used to analyze the data (Hammer, 2017).

\section{Results}

A total of 525 specimens were captured, of which only 375 presented food items in the stomachs. The food spectrum of Plagioscion squamosissimus revealed that the species fed mainly on items of animal origin, being an ingested resource of an accidental form. The diet was composed of five items: shrimp, fish, insect, mollusk and vegetable, the latter rarely found. The shrimp considered as the main item $(\mathrm{IAi}=92.57 \%)$ and insect $(\mathrm{IAi}=7.24 \%)$ as an accessory item in this reservoir (Figure 2).

The region where the Santa Cruz Reservoir was located presented a very characteristic seasonal variation of the semi-arid, with irregular precipitations. In relation to the physical-chemical variables of the water, in general, it is a basic $\mathrm{pH}$ environment, with dissolved oxygen varying between 9 and $4 \mathrm{mg} / \mathrm{l}$ and temperature fluctuating around $32{ }^{\circ} \mathrm{C}$ to $26{ }^{\circ} \mathrm{C}$. As for the related values transparency varied between 317 and $231 \mathrm{~cm}$. Conductivity and total dissolved solids (TDS) presented low oscillations during the study period (Figure 3).

Regarding the temporal variation in the diet, the item shrimp prevailed in all sample, except for February 2012 and November 2013, whose food index values were respectively $39.16 \%$ in February and $56.3 \%$ in November. It is observed that in the months of August the insect item was absent or in low concentration, as well as the mollusk was only observed in the months of February and May in low concentration. Even though it wasn't the main item, the fish was present in the food in almost all analyzed months, except for November 2011 and August 2012, where the feeding of the species was $100 \%$ shrimp.

In the months of February and May of 2011 the food was more varied (Table 1). And in the period

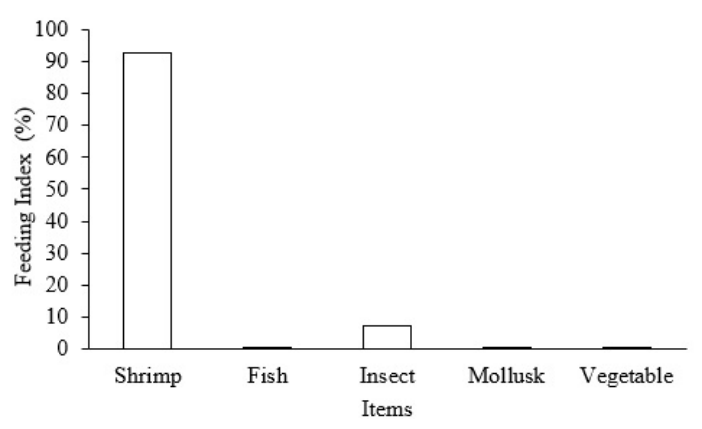

Figure 2. Feeding Index (\%) of the Plagioscion squamosissimus, collected quarterly, between February 2011 and November 2014, at the Santa Cruz Reservoir, Rio Grande do Norte, Brazil. 

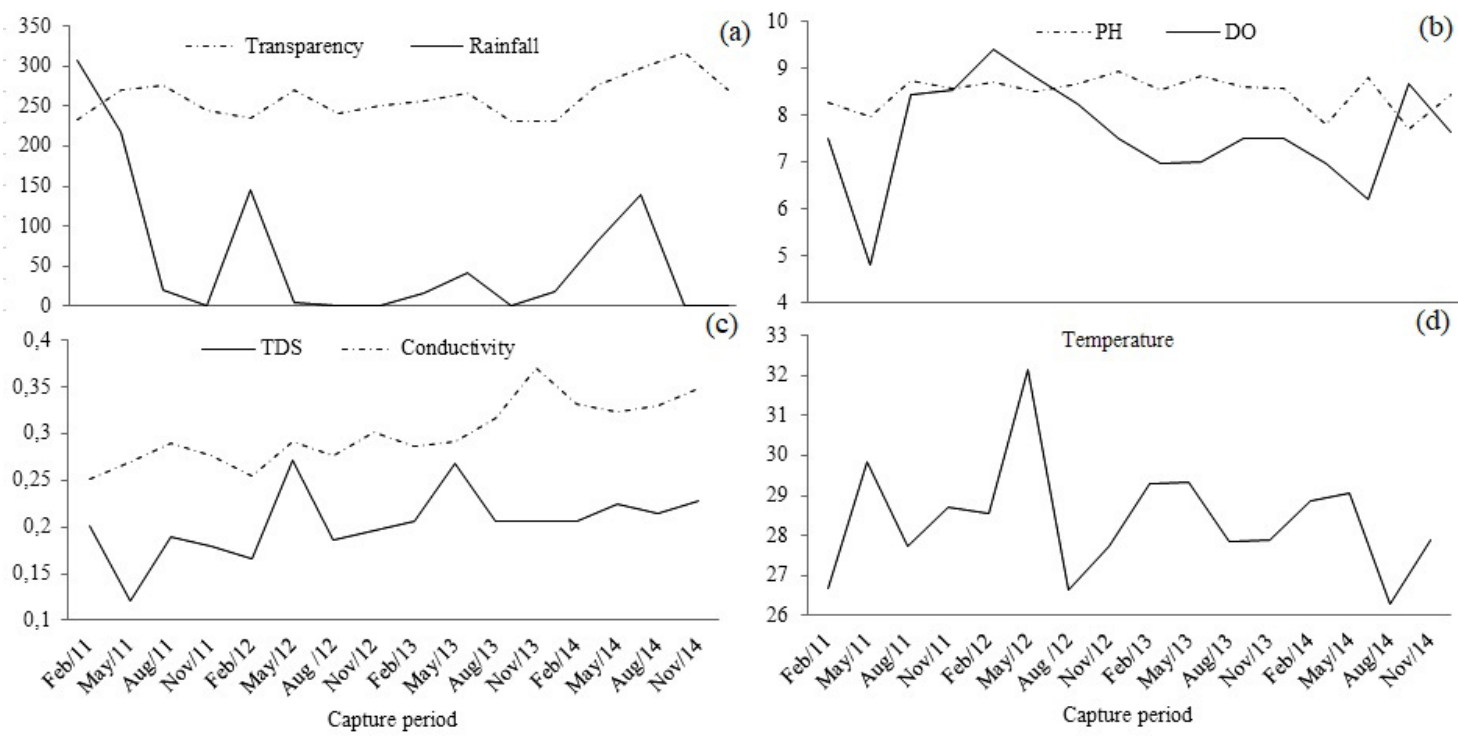

Figure 3. Transparency data (cm), Rainfall (mm) (a), pH, Dissolved Oxygen (DO) (mg/l) (b), Conductivity ( $\mu$ S.cm-1), Total Dissolved Solids (TDS) (g/l) (c), water Temperature $\left({ }^{\circ} \mathrm{C}\right)(\mathrm{d})$, collected quarterly, between February 2011 and November 2014, at the Santa Cruz Reservoir, Rio Grande do Norte, Brazil.

Table 1. Feeding Index (IAi), month and year of sample, of Plagioscion squamosissimus, collected quarterly, between February 2011 and November 2014, at the Santa Cruz Reservoir, Rio Grande do Norte. N - number of stomachs analyzed.

\begin{tabular}{|c|c|c|c|c|c|c|c|}
\hline Year & Mouth & $\mathbf{N}^{\circ}$ & Shrimp & Fish & Insect & Mollusk & Vegetable \\
\hline \multirow[t]{4}{*}{2011} & February & 30 & 91.08 & 1.16 & 7.71 & 0.04 & 0.02 \\
\hline & May & 44 & 94.57 & 1.08 & 3.35 & 0.01 & 0.99 \\
\hline & August & 36 & 99.26 & 0.27 & 0.47 & & \\
\hline & November & 9 & 100 & & & & \\
\hline \multirow[t]{4}{*}{2012} & February & 10 & 39.16 & 14.46 & 46.39 & & \\
\hline & May & 34 & 99.12 & 0.37 & 0.51 & & \\
\hline & August & 20 & 100 & & & & \\
\hline & November & 23 & 90.84 & 9.08 & 0.08 & & \\
\hline \multirow[t]{4}{*}{2013} & February & 19 & 90.9 & 2.2 & 6.7 & 0.1 & \\
\hline & May & 19 & 87.5 & 4.1 & 8.3 & 0.1 & \\
\hline & August & 8 & 82.9 & 17.1 & & & \\
\hline & November & 12 & 56.3 & 38.9 & 4.9 & & \\
\hline \multirow[t]{4}{*}{2014} & February & 5 & 71.43 & 0 & 28.57 & 0 & \\
\hline & May & 40 & 90.21 & 6.45 & 3.18 & 0.16 & \\
\hline & August & 6 & 100 & 0 & 0 & 0 & \\
\hline & November & 60 & 94.76 & 4.75 & 0.46 & 0.02 & \\
\hline
\end{tabular}

when the precipitation was greater, there was a higher insect presence in the feed. The shrimp item was the most abundant in all points, with mollusk between the less abundant items only being present in the individuals caught in the years of 2013 and 2014 and vegetables in 2011 and 2014. Fish and insect although being less abundant was part of the species diet in the four years under study (Table 2).

The temporal ordering (February, May, August and November: $2011-2014$; NMDS stress $=0.03$, Axis 1: 0.92 and Axis 2: 0.35; PERMANOVA F 1.91, $\mathrm{p}=0.10$ ) and spatial (points from 1 to 8: $2011-2014$; NMDS stress = 0.04, Axis 1: 0.94 and Axis 2: 0.46; PERMANOVA F 1.60, $\mathrm{p}=0.09$ ) presented that the species had no variation in the diet between the months and sample points during the study period (Figure 4), which may be related to the high consumption of shrimp in all months and points sampled. The Canonical Correspondence Analysis (CCA, Figure 5, Table 3) indicated a low association between the data of the Feeding Index (IAi) and the environmental variables for the months and points 
Table 2. Feeding Index (IAi), point and year of sample, of Plagioscion squamosissimus, collected quarterly, between February 2011 and November 2014, at the Santa Cruz Reservoir, Rio Grande do Norte. № - number of stomachs analyzed.

\begin{tabular}{|c|c|c|c|c|c|c|c|}
\hline Year & Points & $\mathbf{N}^{\circ}$ & Shrimp & Fish & Insect & Mollusk & Vegetable \\
\hline \multirow[t]{8}{*}{2011} & 1 & 7 & 98.44 & & 1.56 & & \\
\hline & 2 & 9 & 99.02 & 0.79 & 0.19 & & \\
\hline & 3 & 5 & 88.75 & 0.39 & 10.86 & & \\
\hline & 4 & 8 & 98.20 & 1.80 & & & \\
\hline & 5 & 16 & 96.72 & 0.21 & 3.06 & & \\
\hline & 6 & 29 & 97.96 & 1.35 & 0.69 & & \\
\hline & 7 & 16 & 86.42 & & 13.56 & & 0.01 \\
\hline & 8 & 30 & 97.29 & 0.48 & 2.18 & & 0.05 \\
\hline \multirow[t]{8}{*}{2012} & 1 & 4 & 96.30 & & 3.70 & & \\
\hline & 2 & 17 & 94.35 & 4.32 & 1.34 & & \\
\hline & 3 & 7 & 92.16 & 3.13 & 4.70 & & \\
\hline & 4 & 4 & 100.00 & & & & \\
\hline & 5 & 6 & 100.00 & & & & \\
\hline & 6 & 5 & 98.87 & 0.56 & 0.56 & & \\
\hline & 7 & 16 & 99.22 & & 0.78 & & \\
\hline & 8 & 29 & 90.99 & 8.15 & 0.86 & & \\
\hline \multirow[t]{8}{*}{2013} & 1 & 3 & 100.00 & & & & \\
\hline & 2 & 4 & 100.00 & & & & \\
\hline & 3 & 1 & 100.00 & & & & \\
\hline & 4 & 1 & 100.00 & & & & \\
\hline & 5 & 5 & 98.04 & & 1.96 & & \\
\hline & 6 & 3 & 79.72 & 12.49 & 7.79 & & \\
\hline & 7 & 14 & 98.27 & 0.94 & 0.63 & 0.16 & \\
\hline & 8 & 15 & 45.86 & 43.95 & 9.55 & 0.42 & 0.21 \\
\hline \multirow[t]{8}{*}{2014} & 1 & 2 & 100.00 & & & & \\
\hline & 2 & 0 & & & & & \\
\hline & 3 & 4 & 100.00 & & & & \\
\hline & 4 & 28 & 86.91 & 2.64 & 10.21 & 0.24 & \\
\hline & 5 & 7 & 98.04 & 0.44 & 1.31 & 0.22 & \\
\hline & 6 & 2 & 66.67 & & 33.33 & & \\
\hline & 7 & 3 & 100.00 & & & & \\
\hline & 8 & 66 & 81.52 & 7.74 & 8.39 & 2.35 & \\
\hline
\end{tabular}

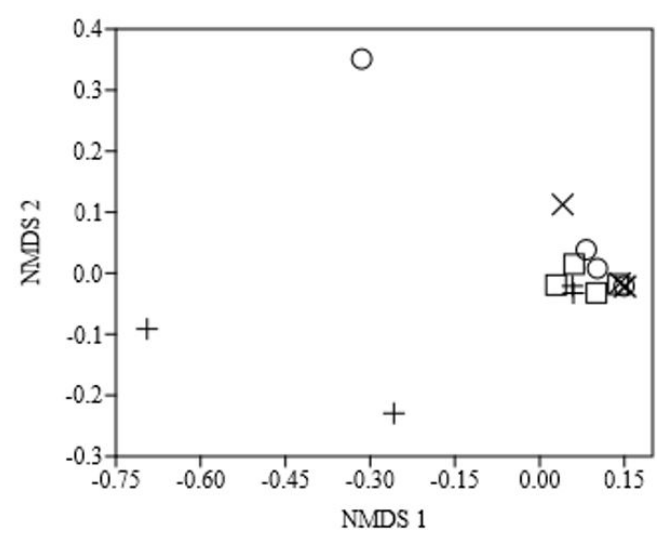

(a)

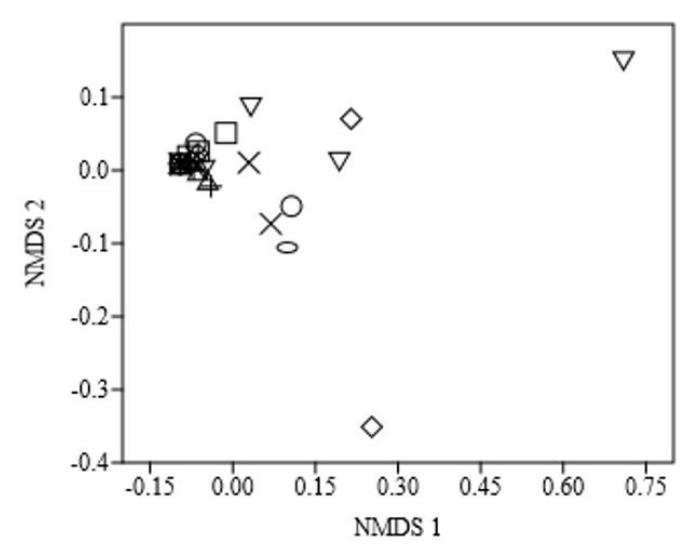

(b)

Figure 4. Non-Metric Multidimensional Scaling (NMDS) of the Plagioscion squamosissimus diet for the months (a) (+ February; $\square$ May; X August; $\circ$ November; 2011 - 2014) and sample points (b) $(+1 ; \square 2 ; X 3 ; \circ 4 ; \triangle 5 ; \diamond 6, \bigcirc 7 ; \nabla 8$; 2011 - 2014) at the Santa Cruz Reservoir, Rio Grande do Norte, Brazil. 


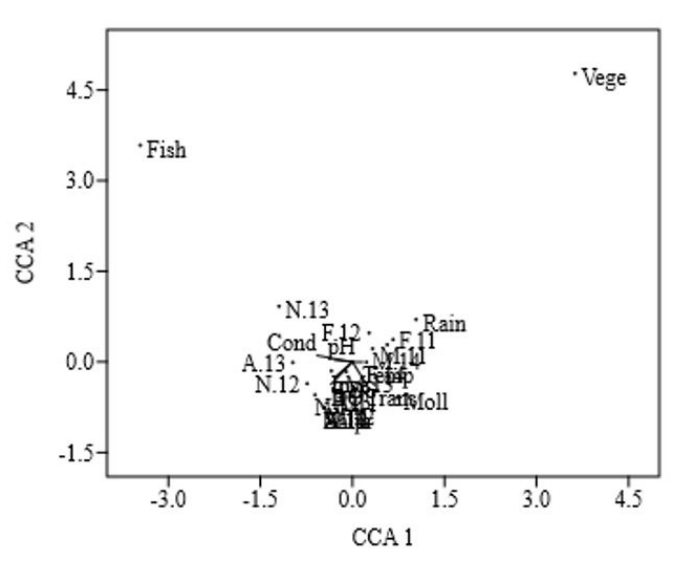

(a)

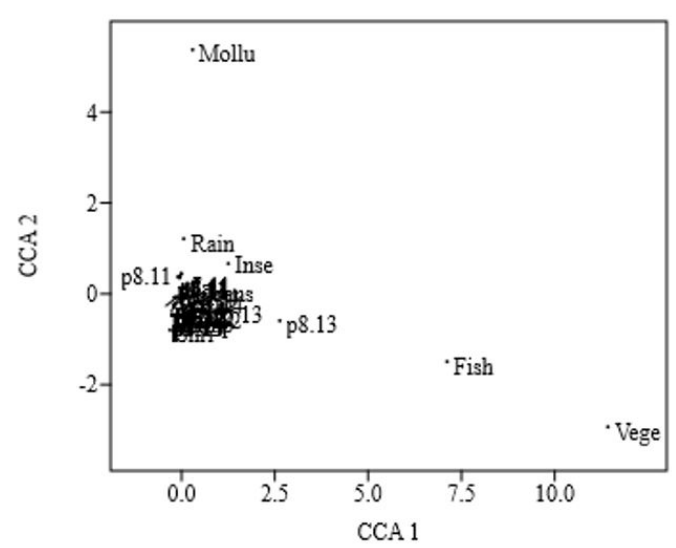

(b)

Figure 5. Canonical Correspondence Analysis (CCA) between the Plagioscion squamosissimus Feeding Index (IAi) data for the months (a) of February (F), May (M), August (A), November (N) from 2011 to 2014, and sample points (b) from 1 to 8 from 2011 to 2014 at the Santa Cruz Reservoir, Rio Grande do Norte, Brazil.

Table 3. Statistical Analysis of Canonic Correspondence Analysis (CCA) between the Plagioscion squamosissimus Feeding Index (IAi) data and the environmental variables for the months and sample points, sampled quarterly, between February 2011 and November 2014, at the Santa Cruz Reservoir, Rio Grande do Norte, Brazil.

\begin{tabular}{cccccc}
\hline \multirow{2}{*}{ Statistical resume } & \multicolumn{2}{c}{ Figure 4. a } & & \multicolumn{2}{c}{ Figure 4. b } \\
\cline { 2 - 3 } \cline { 5 - 6 } & Axis 1 & Axis 2 & & Axis 1 & Axis 2 \\
\hline \% Explanation of axis & 65.79 & 24.32 & & 62.20 & 26.63 \\
Species/Environment Correlation & 0.17 & 0.06 & & 0.08 & 0.03 \\
Monte Carlo simulation "p" & 0.46 & 0.23 & & 0.05 & 0.02 \\
\hline
\end{tabular}

of sample, in this way, the environmental variables don't influence the type of items consumed.

\section{Discussion}

The study of the diet of Plagioscion squamosissimus was possible to classify the species as carcinophagous, corroborating studies by Gavilan-Leandro et al. (2009) and Oliveira et al. (2016b) in Rio Grande do Norte. This has also been demonstrated for the temporal variations, so the shrimp is the item that stands out. Although this isn't considered a common behavior for the species in other regions of Brazil, as observed in the work carried out on the floodplain of the Alto Paraná River (Almeida et al., 1997; Hahn et al., 1999), Barra Bonita dam, Piracicaba (Braga, 1998), which characterized the species as piscivorous.

Bennemann et al. (2006) say that even if the main food of this species in its natural habitat is fish, with the reduction in its availability it becomes opportunistic, replacing it with another food that is abundant. In the case of our study, the shrimp substitute fish, and probably the animal only makes this change when the shrimp is less abundant. Although the shrimp item was the main in all aspects analyzed, it was possible to perceive a certain variation in the secondary items and accessories in the different factors analyzed, with this the species can also be considered generalist and opportunistic. Therefore, changes in diet can be caused by spatial and seasonal changes in habitat, considering that distinct locations and periods have different abiotic conditions and food supply (Moraes et al., 2013; Santos et al., 2014).

During the rainy season, there was a greater tendency to specialize in food (shrimp and fish). On the one hand, the greater diversity and abundance of resources can induce their timely use, resulting in a more generalist food spectrum; on the other hand, tendencies to specialization can be explained by the choice of the most important energy items, among the many offered. It was observed that in 2011 and 2012, where rainfall was higher, the appearance of fish in the diet in almost all points, even in small proportions, due to their occupation in this place, due to the greater 
availability of food and shelter found in marginal vegetation transported from other neighboring ecosystems. According to Barbosa (2002) the vegetation also contributes to a contribution of external material in the body of water that can influence the transparency of the water. Still, shading in this region inhibits phytoplankton growth by making food scarcer for shrimp, in which case fish and insects are more readily available becoming main in the diet.

The characteristics of the environment itself are fundamental for species adaptation in tropical ecosystems, as temperature and luminosity directly contribute to the proliferation of phytoplankton, the main food of shrimp. Consequently, there being more food available for shrimp, there will also be more food availability for the fish, reducing intra and interspecific competition, thus favoring greater reproduction. In addition, when the amount of food is sufficient the animal will not need to have much energy during the foraging. According to Oliveira et al. (2016a), the dietary habits of a species of fish may vary from one locality to another depending on the availability of the trophic resource and the environmental conditions. The shrimp is a prey of easy capture and abundant variation temporal or spatial was not identified.

The water properties reported here did not interfere with feeding, since the results of the parameters evaluated were, for the most part, within the values considered compatible with their survival (Pádua, 2017) and did not suffer sudden variations throughout the year and at the points studied. Among these parameters, the temperature presented typical amplitude for the tropical region, there being no sudden variation of this parameter, which could imply a variation in the oxygen rates in the water, because the higher the temperature, the lower the dissolved oxygen content (Coelho \& Santos-Wisniewski, 2016). These variables affect fish physiology, as observed by Gurgel-Lourenço et al. (2015) in reservoirs in the semi-arid region, where the fish activity was influenced during the highest values of temperature and $\mathrm{pH}$. The alkaline $\mathrm{pH}$ recorded is characteristic of brackish water, especially this parameter, in general, did not present variations outside the range considered susceptible to the biological community $(<5.0$ or $>9.0)$ (Buzelli \& Cunha-Santino, 2013). In relation to the concentrations of dissolved oxygen, although it is a parameter that reflects the presence of organic matter (Coelho \& Santos-Wisniewski,
2016), here they did not demonstrate mains associations with the species.

Therefore, there was not variation in diet in relation to the catch period and the availability of the items consumed was related to the characteristics of both the body of the reservoir and the marginal area. The spatial distribution and in relation to the period did not have a strong impact on the food habit of the species in the studied period, which can be explained by abiotic characteristics that are not very discrepant between reservoir compartments and low precipitation. However, rainfall was an important parameter in the availability and capture of insect and fish. However, the water temperature, transparency, $\mathrm{pH}$, conductivity, dissolved oxygen and total dissolved solids did not influence the food habit of the species.

It was evidenced that in periods of lower precipitation (2012 and 2013) there was a decrease in shrimp consumption by the species, with an increase in the contribution of items such as fish and insects. In the rainy season, according to Gavilan-Leandro et al. (2009), with the increasing volume of water, the shrimp disperses leaving their refuges. On the other hand, shrimp during drought are at the bottom and are less caught (Rabelo \& Araújo-Lima, 2002). During the driest months, insects also contributed to the diet, as they tolerate periods of water scarcity, including those of the Chironomidae and Culicidae families, which can tolerate anoxic conditions (Beserra et al., 2010). It is possible that this same pattern may be occurring in the Santa Cruz reservoir, which explains the increase in shrimp consumption in the months of lower precipitation and the highest contribution of insects and fish in the diet of P. squamosissimus. It is worth noting that in reservoirs, feeding strategies of predatory species are controlled to a greater degree by the availability and susceptibility of their prey than by food preferences (Novakowski et al., 2007).

Although shrimp has been the main food resource in the species diet, it has been proven that fish and insect also make an important role in their diet. P. squamosissimus can present variation between fish and insect as an accessory item when considering different environments or regions. It was also observed that the specie presented carcinophagous food habit, due to the predominance of shrimp in the diet, differentiated from other populations studied in their original habitat, but demonstrates the behavior like other populations studied in the semi-arid region (Gavilan-Leandro et al., 2009; Santos et al., 2014; 
Gurgel-Lourenço et al., 2015; Oliveira et al., 2016b; Souza et al., 2017). This fact evidenced that the species could adapt to the conditions offered by the environment, benefiting from the most abundant and available autochthonous resources, favoring its colonization.

\section{Acknowledgements}

We thank the Conselho Nacional de Desenvolvimento Científico e Tecnológico (CNPq), the Fundação de Apoio à Pesquisa do Estado do Rio Grande do Norte (FAPERN), the Universidade Federal Rural do Semi-Árido (UFERSA). We are grateful the Universidade do Estado do Rio Grande do Norte (UERN) for the financial assistance and the Instituto Federal de Educação, Ciência e Tecnologia do Rio Grande do Norte (IFRN), campus of Apodi, for the logistical support during the field samples.

\section{References}

AGOSTINHO, A.A., GOMES, L.C. and PELICICE, F.M. Ecologia e manejo de recursos pesqueiros em reservatórios do Brasil. Maringá: EDUEM, 2007, $501 \mathrm{p}$.

ALMEIDA, V.L.L., HAHN, N.S. and VAZZOLER, A.E.A.M. Feeding patterns in five predatory fishes of the high Paraná River floodplain (PR, Brazil). Ecology Freshwater Fish, 1997, 6(3), 123-133. http://dx.doi. org/10.1111/j.1600-0633.1997.tb00154.x.

ARAÚJO, D.D.A., OLIVEIRA, J.F., COSTA, R.S. and NOVAES, J.L.C. Population structure and reproduction of a migratory fish Leporinus piau (Characiformes: Anostomidae) in a semiarid tropical reservoir, Brazil. Revista de Biología Tropical, 2016, 64(4), 1369-1381. PMid:29465903.

BARBOSA, J.E.L. 2002. Dinâmica do Fitoplancton e condicionantes limnológicos nas escalas de tempo (nictmerallsazonal) e de espaço (horizontal e vertical) no açude Taperoá II: trópico semi-árido nordestino [Tese de Doutorado em Ecologia e Recursos naturais]. São Carlos: Universidade Federal de São Carlos, 2002. $201 \mathrm{p}$.

BENNEMANN, S.T., CAPRA, L.G., GALVES, W. and SHIBATTA, O.A. Dinâmica trófica de Plagioscion squamosissimus (Perciformes, Sciaenidae) em trechos de influência da represa Capivara (rios Paranapanema e Tibagi). Iheringia. Série Zoologia, 2006, 96(1), 115-119. http://dx.doi.org/10.1590/ S0073-47212006000100020.

BESERRA, E.B., FERNANDES, C.R.M., SOUSA, J.T., FREITAS, E.M. and SANTOS, K.D. The effect of water quality in the life cycle and in the attraction for the egg oviposition of Aedes Aegypti (L.) (Diptera: Culicidae). Neotropical Entomology,
2010, 39(6), 1016-1023. http://dx.doi.org/10.1590/ S1519-566X2010000600026. PMid:21271073.

BRAGA, F.M.S. Alimentação de Plagioscion squamosissimus (Osteichthyes, Sciaenidae) no reservatório de Barra Bonito, Estado de São Paulo. Iheringia. Série Zoologia, 1998, 84(1), 11-19.

BUZELLI, G.M. and CUNHA-SANTINO, M.B. Análise e diagnóstico da qualidade da água e estado trófico do reservatório de Barra Bonita, SP. Revista Ambiente \& Água, 2013, 8(1), 186-205.

CASSEMIRO, F.A.S., HAHN, N.S. and DELARIVA, R.L. Estrutura trófica da ictiofauna, ao longo do gradiente longitudinal do reservatório de Salto Caxias (Rio Iguaçu, Paraná, Brasil), no terceiro ano após represamento. Acta Scientiarum. Biological Sciences, 2005, 27(1), 63-71. http://dx.doi.org/10.4025/ actascibiolsci.v27i1.1362.

COELHO, P.N. and SANTOS-WISNIEWSKI, M.J. Composição da comunidade zooplanctônica em um pequeno corpo d'água raso no Sul de Minas Gerais. Fórum Ambiental da Alta Paulista, 2016, 12(1), 60-74.

COSTA LIMA, M.C.B., LIRA, R.D., BARROS, N.H.C., NASCIMENTO, W.S. and CHELLAPPA, S. Biologia reprodutiva do peixe traíra, Hoplias malabaricus (Bloch, 1794) (Characiformes: Erythrinidae) no açude Marechal Dutra, Rio Grande do Norte, Brasil. Biota Amazônia, 2017, 7(2), 21-25.

FERREIRA FILHO, V.P., GUERRA, T.P., LIMA, M.C.S., TEIXEIRA, D.F., COSTA, R.R., ARAÚJO, I.M.S., EL-DEIR, A.C.A. and MOURA, G.J. Ecomorphological patterns with diet of Plagioscion squamosissimus (Perciformes, Scianidae) in permanent reservoir in northeastern Brazil. Iheringia. Série Zoologia, 2014, 104(2), 134-142. http://dx.doi. org/10.1590/1678-476620141042134142.

GANDINI, C.V., BORATTO, I.A., FAGUNDES, D.C. and POMPEU, P.S. Estudo da alimentação dos peixes no rio Grande à jusante da usina hidrelétrica de Itutinga, Minas Gerais, Brasil. Iheringia. Série Zoologia, 2012, 102(1), 56-61. http://dx.doi. org/10.1590/S0073-47212012000100008.

GANDINI, C.V., SAMPAIO, F.A.C. and POMPEU, P.S. Hydropeaking effects of on the diet of a Neotropical fish community. Neotropical Ichthyology, 2014, 12(4), 795-802. http://dx.doi.org/10.1590/1982-022420130151.

GAVILAN-LEANDRO, S.A.C., PERETTI, D., PINTO-JÚNIOR, J.E.M., FERNANDES, M.A. and GURGEL-JÚNIOR, A.M. Espectro alimentar e variação sazonal da dieta de Plagioscion squamosissimus (Heckel, 1840) (Osteichthyes, Sciaenidae) na lagoa do Piató, Assú, Estado do Rio Grande do Norte, Brasil. Acta Scientiarum. Biological Sciences, 2009, 31(3), 285-292. 
GURGEL-LOURENÇO, R.C., RODRIGUESFILHO, C.A.D.S., ANGELINI, R., GARCEZ, D.S. and SÁNCHEZ-BOTERO, J.I. On the relation amongst limnological factors and fish abundance in reservoirs at semiarid region. Acta Limnologica Brasiliensia, 2015, 27(1), 24-38. http://dx.doi. org/10.1590/S2179-975X2414.

HAHN, N.S., AGOSTINHO, A.A. and GOITEIN, R. Feeding ecology of curvina Plagioscion squamosissimus (Osteichthyes, Perciformes) in the Itaipu reservoir and Porto Rico floodplain. Acta Limnologica Brasiliensia, 1997, 9, 11-22.

HAHN, N.S., LOUREIRO, V.E. and DELARIVA, R.L. Atividade alimentar da curvina Plagioscion squamosissimus (Heckel, 1840) (Perciformes, Sciaenidae) no rio Paraná. Acta Scientiarum. Biological Sciences, 1999, 21(2), 309-314.

HAMMER, O. PAST - PAleontological STatistics, version 3.14 [online]. Oslo: PAST, 2017 [viewed 12 Set. 2017]. Available from: http://folk.uio.no/ohammer/ past/

HELLAWELL, J.M. and ABEL, R. A rapid volumetric method for the analysis of the food of fishes. Journal of Fish Biology, 1971, 3(1), 19-37. http://dx.doi. org/10.1111/j.1095-8649.1971.tb05903.x.

KAWAKAMI, E. and VAZZOLER, G. Método gráfico e estimativa de índice alimentar aplicado no estudo de alimentação de peixes. Boletim do Instituto Oceanográfico, 1980, 29(2), 205-207. http://dx.doi. org/10.1590/S0373-55241980000200043.

LOURES, R.C. and POMPEU, P.S. Temporal variation in fish community in the tailrace at Três Marias Hydroelectric Dam, São Francisco River, Brazil. Neotropical Ichthyology, 2012, 10(4), 731-740. http:// dx.doi.org/10.1590/S1679-62252012000400006.

MCCAFFERTY, W.P. Aquatic entomology: the fishermen's and ecologist's illustrated guide to insects and their relatives. Boston: Jones and Bartlett Publishers, 1981, $448 \mathrm{p}$.

MERRITT, R.W. and CUMMINS, K.W. An introduction to the aquatic insects of North America. 3. ed. Dubuque: Kendall/Hunt, 1996, 722 p.

MORAES, M., REZENDE, C.F. and MOZZONI, R. Feeding ecology of stream-dwelling Characidae (Osteichthyes: Characiformes) from the upper Tocantins River, Brazil. Zoologia, 2013, 30(6), 645-651. http://dx.doi.org/10.1590/S198446702013005000003 .

NEEDHAM, J.G. and NEEDHAM, P.R. Guia para el estudio de los seres vivos de las aguas dulces. Barcelona: Reverté S.A, 1982, 131 p.

NOVAES, J.L.C., MOREIRA, S.I.L., FREIRE, C.E., SOUSA, M.M.O. and COSTA, R.S. Fish assemblage in a semi-arid Neotropical reservoir: composition, structure and patterns of diversity and abundance. Brazilian Journal of Biology $=$ Revista Brasileira de Biologia, 2014, 74(2), 290-301. http://dx.doi. org/10.1590/1519-6984.14712. PMid:25166313.

NOVAKOWSKI, G.C., HAHN, N.S. and FUGI, R. Alimentação de peixes piscívoros antes e apos a formação do reservatório de Salto Caxias, Parana, Brasil. Biota Neotropica, 2007, 7(2), 149-154. http:// dx.doi.org/10.1590/S1676-06032007000200017.

OLIVEIRA, J.F., COSTA, R.S., NOVAES, J.L.C., REBOUÇAS, L.G.F., MORAIS-SEGUNDO, A.L.N. and PERETTI, D. Efeito da seca e da variaçáo espacial na abundância de indivíduos nas guildas tróficas da ictiofauna em um reservatório no Semiárido Brasileiro. Boletim do Instituto de Pesca, 2016a, 42(1), 51-64. http://dx.doi.org/10.20950/1 678.2305.2016v42n1p51.

OLIVEIRA, J.F., MORAES-SEGUNDO, A.L., NOVAES, J.L., COSTA, R.S., FRANÇA, J.S. and PERETTI, D. Trophic structure of the ichthyofauna in a Brazilian semiarid reservoir. Iheringia. Série Zoologia, 2016b, 106, 1-9.

PACHECO, C.B. and BAUMANN, J.C. Apodi: um olhar em sua biodiversidade. Natal: Copyright, 2006.

PÁDUA, H.B. Temperatura (águalar) em sistemas aquáticos [online]. ABRAPPESQ, 2017 [viewed 12 Set. 2017]. Available from: http://www.pescar.com. $\mathrm{br} /$ helcias/

RABELO, H. and ARAÚJO-LIMA, C.A.R.M. A dieta e o consumo diário de alimento de Cichla monoculus na Amazônia Central. Acta Amazonica, 2002, 32(4), 707-724. http://dx.doi.org/10.1590/180943922002324724.

REIS, L.R.G. and SANTOS, A.C.A.S. Dieta de duas espécies de peixes da família Cichlidae (Astronotus ocellatus e Cichla pinima) introduzidos no rio Paraguaçu, Bahia. Biotemas, 2014, 27(4), 84-91.

ROSECCHI, E. and NOUAZE, Y. Comparaison de cinq índices alimentaires utilisés dans I' analyse descontenus stomacaus. Revue des Travaux de l'Institut des Pêches Maritimes, 1985, 49(3-4), 111-123.

SANTOS, G.M. Impactos da hidrelétrica Samuel sobre as comunidades de peixes do rio Jamari (Rondônia, Brasil). Acta Amazonica, 1995, 25(3-4), 247-280. http://dx.doi.org/10.1590/1809-43921995253280.

SANTOS, N.C.L., MEDEIROS, T.N., ROCHA, A.A.F., DIAS, R.M. and SEVERI, W. Uso de recursos alimentares por Plagioscion squamosissimus - piscívoro não-nativo no reservatório de sobradinho - BA, Brasil. Boletim do Instituto de Pesca, 2014, 40(3), 397-408.

SECRETARIA DE ESTADO DE MEIO AMBIENTE E DOS RECURSOS HÍDRICOS - SEMARH. Quadro das principais barragens da bacia do rio Apodi - Mossoró [online]. Natal: SEMARH, 2014 [viewed 12 Set. 2017]. Available from: http://www. semarh.rn.gov.br

SILVA, D.A., PESSOA, E.K.R., GAVILAN-LEANDRO, S.A.C., CHELLAPPA, N.T. and CHELLAPPA, S. 
Ecologia alimentar de Astyanax lacustris (Osteichthyes: Characidae) na Lagoa do Piató, Assu, Rio Grande do Norte, Brasil. Biota Amazônia, 2012, 2(1), 74-82. http://dx.doi.org/10.18561/2179-5746/ biotaamazonia.v2n1 $74-82$.

SIQUEIRA-SOUZA, F.K. and FREITAS, C.E.C. Fish diversity of floodplain lakes on the lower stretch of the Solimóes River. Brazilian Journal of Biology = Revista Brasileira de Biologia, 2004, 64(3), 1-10. PMid:15622847.

SOUZA, A.E.F., OLIVEIRA, J.F., PERETTI, D., FERNANDES, R., COSTA, R.S. and NOVAES, J.L.C. Effects of a Supraseasonal Drought on the Ecological Attributes of Plagioscion squamosissimus (Heckel, 1840) (Pisces, Sciaenidae) in a Brazilian
Reservoir. The Scientific World Journal, 2017, 2017, 1-9. http://dx.doi.org/10.1155/2017/5930516. PMid:28326431.

YAMAMOTO, K.C., SOARES, M.G.M. and FREITAS, C.E.C. Alimentação de Triportheus angulatus (Spix e Agassiz, 1829) no Camaleão, Manaus, Amazonas, Brasil. Acta Amazonica, 2004, 34(4), 653-659. http:// dx.doi.org/10.1590/S0044-59672004000400017.

ZAVALA-CAMIN, L.A. Introdução aos estudos sobre alimentação natural em peixes. Maringá: EDUEM, 1996, 129 p.

Received: 30 November 2016

Accepted: 14 September 2018 